\title{
Drivers that Change the Direction of Penal Policy: A Case of Developments of Victim-Offender Reconciliation in the Lithuanian Criminal Justice System ${ }^{1}$
}

\author{
BY SKIRMANTAS BiKELIS*
}

\begin{abstract}
The paper presents a recent significant shift in Lithuanian penal policies on non-serious crimes where the punitive approach has given way to the restorative approach. It discusses the preconditions of this change with a particular focus on the attitudes of Lithuanian judicial authorities. In contrary to the common stereotypes and academic opinions that criminal justice system holds onto hard-line policies with a high degree of inertia, the results of the research reveals that prosecutors and judges favor the pragmatic alternative ways for solving victimoffender conflicts. Their approach is based on the conviction that full-scale prosecution and punishment for nonserious crimes often impede primary victims' needs and places an unreasonable burden on the criminal justice system. This approach allows us to anticipate good perspectives for the implementation of the victim-offender mediation services in the Lithuanian criminal justice system.
\end{abstract}

Keywords: victim-offender mediation, victims' needs, reconciliation, termination of criminal proceedings

\section{BACKGROUND}

Fifteen years have passed since the Council of Europe Committee of Ministers issued Recommendation No. R (99) 19 on mediation in penal matters. ${ }^{2}$ In 2012 Directive 2012/29/ EU of the European Parliament and of the Council establishing minimum standards on the rights, support and protection of victims of crime, and replacing Council Framework Decision 2001/220/JHA came into force providing for the legally binding requirement that Member States are to facilitate the referral of cases, as appropriate to restorative justice services. ${ }^{3}$ Lithuania, however, appears to be one of the last European countries that still have not introduced mediation services in criminal matters. Development of the system of mediation services is still in the early stages. Other States in the Baltic region (Latvia, Estonia, Poland) have been providing mediation services in penal matters for several years. In Estonia the conciliation service was implemented in February 2007. ${ }^{4}$ In Latvia victimoffender mediation in criminal cases is carried out by the State Probation Service since

1 The paper presents a piece of results from the research "Perspectives of Restorative Justice in Lithuania", which has been conducted by the Law Institute of Lithuania and has been funded by the Research Council of Lithuania under agreement No. MIP-016/2013.

2 Adopted by the Committee of Ministers on 15 September 1999 at the meeting of the Ministers' Deputies, <https://wcd.coe.int/ViewDoc.jsp?id=420059\&Site=DC $>$ accessed 14 September 2014.

3 [2012] OJ L 315/67.

4 Social Insurance Board of the Republic of Estonia, <http://www.sotsiaalkindlustusamet.ee/ conciliation-service-2/> accessed 15 December 2014.

*Chief research fellow, Law Institute of Lithuania, Criminal Justice Researches Department, <www. teise.org>, e-mail: skirmantas.bikelis@gmail.com. 
2005. ${ }^{5}$ Since 1 September 1998 mediation has been formally used in the Polish criminal law system. In the beginning, mediation sessions were conducted only at the stage of preparatory proceedings and at the very early stage of judicial proceedings (during the preliminary judicial control over the indictment). In 2003, however, the law was changed in favor of the mediation process. ${ }^{6}$

In the research "Perspective of Restorative Justice in Lithuania" a few hypotheses are raised as to why mediation services have been so slowly integrated into criminal matters in Lithuania. $^{7}$ One of the hypotheses states that legal openings for victim-offender reconciliation, provided in the current legal framework, might make an impression that there would be little added value in further developments towards the mediation services. The second hypothesis states that judicial authorities favor conservative and punitive approaches. Altogether it results in the criminal justice authorities' resistance to the introduction of mediation services in the penal matters in Lithuania.

However, the results of our research proved that the aforementioned hypotheses are unfounded. In addition, it allowed us to anticipate for the necessary support of judicial authorities for the introduction of mediation services in penal matters.

\section{PRECONDITIONS FOR CONFLICT RESOLUTION IN LITHUANIA}

Although the mediation services in penal matters are not available, Lithuanian penal laws allow for some legal openings for the victim-offender reconciliation. Article 38 of the Penal Code provides release from criminal liability due to the victim-offender reconciliation. The ground for this release is the diversion of criminal proceedings. ${ }^{8}$ Chapter 30 of the Code of Criminal Proceedings provides for the private prosecution procedure. ${ }^{9}$ The grounds and legal consequences of these legal instruments are provided and compared in Table 1.

5 Ilona Kronberga, Indra Mangule and Sanita Sīle, 'Restorative Justice in Latvia: Advancement, Perspectives and Challenges in Future' (2013) <http://providus.lv/upload_file/Publikacijas/Kriminalt/ Restorative_Justice_Latvia_Report.pdf> accessed 15 December 2014.

${ }^{6}$ Elzbieta Czwartosz, 'Victim - Offender Mediation. Short notes from Poland' (2004) <www. restorativejustice.org/10fulltext/czwartosz/at_download/file> accessed 15 December 2014.

7 Ilona Michailovič, Skirmantas Bikelis, Algimantas Čepas, Margarita Dobrynina, Rimantas Simaitis, Darius Šneideris, Laura Ūselè, Judita Venckevičienè, Atkuriamojo teisingumo perspektyvos Lietuvoje [Restorative Justice Perspectives in Lithuania] (Research Series of Law Institute of Lithuania 2014).

8 Penal Code of the Republic of Lithuania [Lietuvos Respublikos baudžiamasis kodeksas], OG, 2000, No. 89-2741.

9 Code of Criminal Proceedings of the Republic of Lithuania [Lietuvos Respublikos baudžiamojo proceso kodeksas], OG, 2002, No. 37-1341. 
Table 1. Diversion upon victim-offender reconciliation

\begin{tabular}{|c|c|c|}
\hline & $\begin{array}{l}\text { Release from criminal liability upon } \\
\text { victim-offender reconciliation }\end{array}$ & Private prosecution procedure \\
\hline $\begin{array}{l}\text { Legal } \\
\text { grounds }\end{array}$ & Art. $38 \mathrm{PC}$ & Art. 407-413 CCP \\
\hline $\begin{array}{l}\text { Stage of } \\
\text { criminal } \\
\text { proceedings }\end{array}$ & Pre-trial investigation or (and) trial & $\begin{array}{l}\text { Trial (pre-trial investigation is not } \\
\text { provided in these cases unless the case is } \\
\text { diverted to the public prosecution due to } \\
\text { its importance to the public) }\end{array}$ \\
\hline $\begin{array}{l}\text { Categories of } \\
\text { the criminal } \\
\text { acts }\end{array}$ & $\begin{array}{l}\text { Misdemeanors, negligent offences, non- } \\
\text { serious intentional offences with } \\
\text { maximum sanction up to } 6 \text { years (in } \\
\text { practice most common: causing physical } \\
\text { pain or a negligible health impairment } \\
\text { against a child or in a domestic } \\
\text { environment, non-serious health } \\
\text { impairment, road offences [except for } \\
\text { drunk driving], violation of public order, } \\
\text { thefts) }\end{array}$ & $\begin{array}{l}\text { Negligible health impairment (except } \\
\text { against a child or in the domestic } \\
\text { environment), libel, insult, intentional } \\
\text { property damage (except if the value is } \\
\text { significant) }{ }^{10} \text { negligent non-serious } \\
\text { impairment of health, restriction of } \\
\text { person's liberty, sexual harassment, } \\
\text { intrusion into person's dwelling, unlawful } \\
\text { collection of personal data, negligent } \\
\text { damage to property, contempt for the } \\
\text { memory of the deceased }\end{array}$ \\
\hline $\begin{array}{l}\text { Grounds } \\
\text { provided by } \\
\text { law }\end{array}$ & $\begin{array}{l}\text { An offender: } \\
\text { 1) confessed to commission of the } \\
\text { criminal act } \\
\text { 2) voluntarily compensated for or } \\
\text { eliminated the damage incurred to a } \\
\text { natural or legal person or agreed on the } \\
\text { compensation for or elimination of this } \\
\text { damage } \\
\text { 3) reconciled with the victim or a } \\
\text { representative of a legal person or a } \\
\text { state institution } \\
\text { 4) there is a basis for believing that he or } \\
\text { she will not commit new criminal acts }\end{array}$ & $\begin{array}{l}\text { Parties reconcile or private prosecutor } \\
\text { withdraws charges }\end{array}$ \\
\hline Restrictions & $\begin{array}{l}\text { 1) Offender is recidivist or dangerous } \\
\text { recidivist } \\
\text { 2) Offender had already been released } \\
\text { from criminal liability on the basis of } \\
\text { reconciliation with the victim and less } \\
\text { than four years had elapsed from the } \\
\text { day of reconciliation until the } \\
\text { commission of a new crime }\end{array}$ & Not provided \\
\hline $\begin{array}{l}\text { Legal } \\
\text { consequences }\end{array}$ & $\begin{array}{l}\text { Offender may be released from criminal } \\
\text { liability. In this case, the proceedings are } \\
\text { terminated, and offender may be subject } \\
\text { to the court injunctions and obligations }\end{array}$ & Termination of proceedings \\
\hline
\end{tabular}

10 Private prosecution cases for the first four categories of offences on this list make ca. $97 \%$ of all private prosecution cases. 
Table 1. cont.

\begin{tabular}{|l|l|l|}
\hline & $\begin{array}{l}\text { Release from criminal liability upon } \\
\text { victim-offender reconciliation }\end{array}$ & Private prosecution procedure \\
\hline $\begin{array}{l}\text { Grounds to } \\
\text { revoke a } \\
\text { decision to } \\
\text { terminate } \\
\text { proceedings }\end{array}$ & $\begin{array}{l}\text { 1) Upon the decision of the court, if } \\
\text { offender fails to fulfill the agreement } \\
\text { on compensation of damage }\end{array}$ & Not provided \\
& $\begin{array}{l}\text { Upfen the decision of the court, if } \\
\text { negligent crime within one year or he/ } \\
\text { she fails to obey court injunctions or } \\
\text { obligations }\end{array}$ & \\
& $\begin{array}{l}\text { 3) Automatically, if an offender commits } \\
\text { intentional crime within one year }\end{array}$ & \\
\hline
\end{tabular}

Both procedures are rather progressive as they encourage the parties to pursue the solution of the conflict actively and allow diversion from full-scale criminal proceedings. Nevertheless, compared to the mediation services they have some significant disadvantages. First, they leave the parties to make contact on their own initiative without any help and support from the well-trained mediation specialists. No specialist who could provide guidance, support and safeguard for the contact of the parties in present reconciliation proceedings is available. No effort is usually made to mitigate the psychological tension between the parties and to provide support for the victim to cope with fear and confusion. Thus the spirit of restorative justice is little respected. The reconciliation proceedings are usually nothing more than the negotiations of the parties on the material compensation where the dispute on the amount of non-pecuniary damages is the main issue. ${ }^{11}$

Moreover, in the pre-trial investigation stage during arrangements for reconciliation agreement, parties often do not meet each other personally. It is common practice to contact and make an agreement on reconciliation via the officer of the pre-trial investigation who acts as a "shuttle" between the parties. Prosecutors, that we have interviewed, told us that pre-trial investigators have neither time nor competence to organize and moderate the faceto-face meetings of the parties.

When the grounds for the application of Art. 38 PC are present, the pre-trial investigators or the prosecutors inform the parties about the possibility to make a reconciliation agreement. Sometimes officers even make efforts to encourage the parties to reconcile. However, they are not eager to engage in such activities as they risk facing suspicions from both parties of the proceedings. A victim may suspect a pro-active officer as having corrupt intentions to help an offender evade criminal liability. An offender may suspect the officer of pursuing hidden intentions of attempting to extract his confession for the purposes of successful prosecution.

11 In domestic violence cases even the issue of material compensation is mostly irrelevant as parties share the same budget. Common perception of minor physical violence as the legitimate educational measure against a child caused a spike in criminal prosecutions against parents under new laws against domestic violence. In these cases prosecutions are being commonly terminated on the ground of Art. $38 \mathrm{CC}$ due to the reconciliation between the suspected parent and the parent who represents the interests of the victim (a child) in the proceedings. The spirit of restorative justice may be hardly found in the proceedingss of this kind. They rather serve as a formal instrument for reducing the intrusion of criminal justice into family issues. 


\section{STATISTICS DATA ON THE APPLICATION OF ART. 38 OF PC} OF LITHUANIA

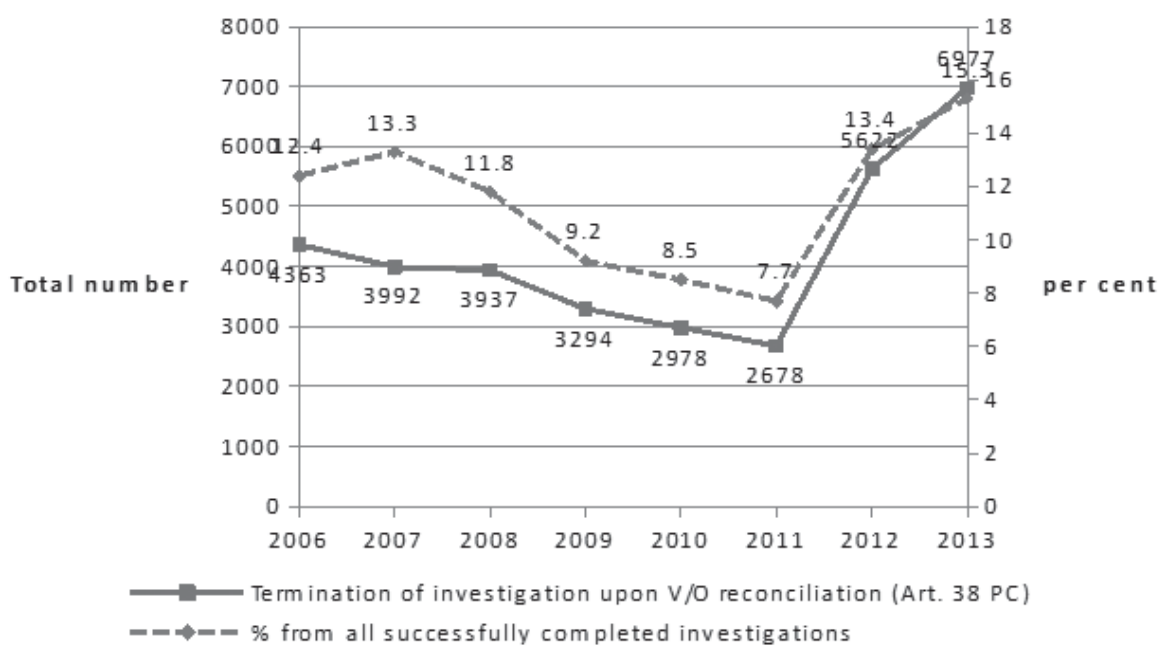

Diagram 1. Dynamics of releases from criminal liability upon the victim--offender reconciliation under Art. 38 of PC in 2006-2013

Diagram 1 shows extremely dynamic changes in a number of cases where Art. 38 of PC has been applied during the pre-trial investigation. In 2006-2011, the number of releases from the criminal liability under Art. 38 PC decreased consistently in total by $39 \%$. After that it doubled in 2012-2013. During this period, there have been no significant amendments to Art. 38 PC, which could affect such dramatic changes in statistics. It appears that we are given an opportunity to identify the drivers other than the amendments of penal laws directly introducing new regulation for diversion, which caused the significant changes in the course of penal policy towards the alternatives to the conviction and punishment of the offenders.

The decreasing trend in 2006-2011 may look quite surprising. Recent interviews with the prosecutors and judges ${ }^{12}$ have shown their deeply motivated support for a peaceful resolution of conflict and a consequent diversion from criminal proceedings. Unanimity and reasonable motivation of their attitudes allows us to make a cautious supposition that it could be a widely accepted attitude among the criminal justice authorities in Lithuania. Moreover, as personal attitudes are rather persistent, it is even more surprising that there is such an extreme change in trend of statistics of releases from criminal liability since 2012. It appears that prosecutors' positive attitudes regarding the victim-offender reconciliation and diversion of settled conflicts used to be constantly inhibited in 2006-2011 and since 2012 they have burst the river banks.

In 2012, the Lithuanian criminal policy experienced several changes that might be reflected in the dynamics of the data presented in Diagram 1. First, the Prosecutor General of Lithuania declared new priorities for the results of the prosecution in the Strategic Plan

12 For detailed opinions of Lithuanian judicial authorities see below. 
for Prosecution ${ }^{13}$. Termination of pre-trial investigation upon victim-offender reconciliation was declared as prima ratio. Additionally, referral of the case to the court for trial was named as ultima ratio. Prosecutors were given recommendations to refer criminal cases to the court only if the diversion from criminal proceedings and application of the simplified proceedings (i.e. the penal order where non-custodial sanction may be imposed without the court hearing of the case if the offender consents) were impossible.

Another important circumstance is very prosaic. Since 2012, the rules on reports on prosecutors' workload where maximum workload value was provided for finishing of pretrial investigation with reference of the case for the trial have been abolished. In the case of diversion of criminal proceedings, a prosecutor could "earn" fewer work-load points. This work-load accounting system encouraged prosecutors to avoid diversion from criminal proceedings thus improving their work-load rates.

One more factor, which has driven changes in the criminal policies and has been mirrored in the data, was the Law on Protection against Domestic Violence (LPDV), which came into force on 26th May 2011. ${ }^{14}$ The law withdrew the victim's right to decide if violent ${ }^{15}$ domestic conflicts (even minor) should be managed by the criminal justice system. When the Law came into force, police officers were given a duty to initiate pre-trial investigation without regard to whether the victim had filed a complaint or not. After the law came into force (relevant amendments of Code of Criminal Proceedings came into force as late as 13 July 2013, but aforementioned provision has been put into practice right after the enactment of the LPDV), the number of pre-trial investigations on domestic violence skyrocketed. So did the number of the cases which have been terminated and the offenders have been released from criminal liability due to the victim-offender reconciliation upon Art. 38 PC. Unfortunately, no relevant statistics on specifically domestic violence pretrial investigations are available. Instead, statistics on causing physical pain or a negligible health impairment under Art. 140 PC are at hand. As currently this is the most common domestic violence offence, these statistics could serve as an indirect indicator of the impact of new legislation on protection against domestic violence on statistics of termination of pre-trial investigations upon Art. 38 PC. The fact (which was mentioned in the interviews with prosecutors) that pre-trial investigations on Art. $140 \mathrm{PC}$ are terminated mostly on the ground of Art. 38 PC also help to infer some conclusions from the available statistics.

Table 2. Terminated pre-trial investigations under Art. 140 PC

\begin{tabular}{|l|l|l|l|l|}
\hline & $\mathbf{2 0 1 0}$ & $\mathbf{2 0 1 1}$ & $\mathbf{2 0 1 2}$ & $\mathbf{2 0 1 3}$ \\
\hline Total & 191 & 161 & 2651 & 4061 \\
\hline Share of all completed pre-trial investigations (\%) & 18.5 & 13 & 34.3 & 38 \\
\hline
\end{tabular}

13 Strategic Plan for Prosecution for 2012-2014, Prosecutor General of the Republic of Lithuania, <www.prokuraturos.lt/Veikla/Planavimodokumentai/Strateginiaiveiklosplanai/tabid/516/ Default.aspx $>$ accessed 12 April 2014.

14 The Law on Protection against Domestic Violence [Apsaugos nuo smurto artimoje aplinkoje istatymas], OG, 2011, No. 72-3475.

15 The Law provides broad comprehensive definition of violence: an intentional physical, mental, sexual, and economic or other influence exerted on a person by an act or omission as a result whereof the person suffers physical, property or non-pecuniary damage. 
It is evident that the timing and scale of the increase in terminated cases on Art. 140 $\mathrm{PC}$ strongly correlates with the dynamics in statistics of cases terminated due to $\mathrm{V} / \mathrm{O}$ reconciliation under Art. 38 PC (see Diagram 1). However, it would not be reasonable to assume that the increase of pre-trial investigations that had been terminated due to $\mathrm{V} / \mathrm{O}$ reconciliation under Art. $38 \mathrm{PC}$ rests exclusively on the new legislation on protection against domestic violence. Trends of the more frequent application of Art. 38 in criminal proceedings may be observed in other types of criminal proceedings as well: road offences, violation of public order, thefts and minor violence in a non-domestic environment. It has been confirmed in the interviews with prosecutors and judges, and it may be observed in the statistics on criminal proceedings of different offence categories.

We may conclude that the great variety of circumstances may affect trends in the penal policy. Even without significant amendments of the legal grounds for release upon victimoffender reconciliation, the practice of implementation of this norm may change remarkably due to the new legislation concerning a single category of offences (though very common offences) and because of new organizational measures in the system of prosecution: establishment of new priorities of prosecution and change of the criteria for prosecutors' workload accounting. Bottom-up support among low ranking prosecutors for a legal instrument seems to be insufficient for bringing implementation of that legal instrument into common practice. A top-down stimulus is necessary. Alternatively, we may assume that the bilateral effect exists. It is doubtful if implementation of Art. 38 PC would become common in practice without the bottom-up support even after new priorities are set by the Prosecutor General. The same is probably true for implementing mediation services.

\section{VIEWS OF JUDICIAL AUTHORITIES ON VICTIMS' NEEDS AND ADDED VALUE OF MEDIATION IN PENAL MATTERS}

There is no need to argue that judicial authorities (judges and prosecutors), who are the gatekeepers for the restorative justice practices, play the key role in the developments of mediation services in penal matters. There would be little chance for successful implementation of mediation services into the practice if the judicial authorities would not admit that mediation could bring added value to the interests of the parties of the criminal proceedings.

We have inquired into the attitudes of the prosecutors and judges from two perspectives. The first one was more general. We addressed their views on the primary victims' needs in the course of the criminal proceedings. The second perspective was more specific and twofold: first, if judicial authorities' favored diversion from criminal proceedings and second, if they assume that mediation services could bring any added value to the current state of art.

We approached these issues by conducting in-depth face-to-face interviews with seven prosecutors and five judges who have rich experience in victim-offender reconciliation in criminal proceedings for non-serious crimes under Art. $38 \mathrm{PC}$ or in private prosecution cases. In conducting these interviews and the analysis of the data we employed the qualitative research methods based on the data saturation principle.

\section{Views of Judicial Authorities on Victims' Needs}

The judicial authorities shared quite a unanimous opinion that compensation for damages is one of the most important interests of the victims. In criminal proceedings the offender may pay damages on a voluntary basis or he/she may be ordered to do so by the final judgment 
of the court. Voluntary recovery of the damage (which is one of the conditions for offender's release from criminal liability under Art. 38 PC) is more favorable for the victim. First, it is a question of time. If a victim and an offender reconciled and concluded an agreement which included payments for damages at the beginning of proceedings during the pre-trial investigation, the victim may receive compensation (or to begin to receive if an agreement on timetable for payments has been reached) immediately. He or she would not need to wait for it until the pre-trial investigation ends, the case is heard at the court of first instance and probably at the court of appellate instance. Secondly, the victim has better chances to recover damages in a timely manner and in full after voluntary agreement with an offender and his/her consequent release from criminal liability under Art. 38 PC, because the alternative scenario, where full-scale criminal proceedings are held and a sanction is imposed, would decrease offender's capacity to pay damages. ${ }^{16}$

Respondents also noted another need of the victim, which is of paramount importance and which may outweigh all the other needs. It is the need for regard and respect. ${ }^{17}$ In the sample interviews from daily practice which have been provided, the reconciliation proceedings failed because of the arrogant approach of one of the parties (which in response is often mirrored by the opposite party). On the contrary, there had been cases where victims were satisfied with a relatively small amount of compensation and declared that they forgive the offender after the latter had shown his respect and concern for the victim (i.e. the offender visited the victim at hospital, was concerned about his or her health).

Public common sense and often media tell us that the primary desire of a victim is revenge for the offence committed against him or her. Indeed, research in the field of psychology shows that there is a desire for retribution as an immediate emotional reaction of many victims. ${ }^{18}$ The prosecutors and judges that we have interviewed admitted this fact. The shared opinion of prosecutors and judges is that this initial emotional reaction should not be overestimated. In many cases victims' desire for retribution diminishes after some time. ${ }^{19}$ Therefore after some time instead of retribution and revenge victims prefer compensation for damage, support and sincere apology from the offender. Similar findings come from academic research papers on victims' needs. ${ }^{20}$

16 Heather Strang also observes that "most victims who attempt to obtain compensation through the criminal justice process are not likely to receive it". Heather Strang, cited by Ivo Aertsen et al., Victims and resorative justice. An empirical study of the needs, experiences and position of victims within restorative justice practices (European Forum for Restorative Justice 2013) 27.

17 Cf. Howard 7.

18 Ruth Reches, 'Psichologinio pasipriešinimo atkuriamajam teisingumui problema' [The Issue of Psychologic Resistance to the Restorative Justice] (2010) 2/6 Socialinių mokslu studijos 357, 364 365; Brad J. Bushman, Roy F. Baumeister, Colleen M. Phillips, 'Do People Aggress to Improve Their Mood? Catharsis Beliefs, Affect Regulation Opportunity, and Aggressive Responding' (2001) 81 Journal of Personality and Social Psychology 17, 30.

19 Cf. Ezzat Fattah, 'Victim Redress and Victim-Offender Reconciliation in Theory and Practice. Some Personal Reflections’ (1999) 35/1 The Hokkaigakuen Law Journal 87-101.

${ }^{20}$ Cf. Bolívar 32. 


\section{VIEWS OF JUDICIAL AUTHORITIES ON ADDED VALUE OF MEDIATION IN PENAL MATTERS}

The interviews have shown that prosecutors and judges unanimously favor diversion from criminal proceedings for non-serious crimes, and they acknowledge the added value of the victim-offender mediation. Their motivation rests on two main pillars: on their concern for the economy of proceedings, and on their concern for the needs of the parties and society in general.

The thesis that criminal justice officers are skeptical and even show resistance to the idea of restorative justice, thus shading the perspectives of acceptance of restorative justice ideas in practice, is commonly accepted in public. It has been repeatedly asserted in the academic publications. Reches writes that "opposition of criminal justice system to implementation of ideas of restorative justice is generally accepted fact. This opposition is linked to conservatism of this branch of law, and its resistance to new ideas". ${ }^{21}$ Michailovič cites experts' opinion that one of the obstacles for implementation of mediation is resistance to the idea of restorative justice among police officers, prosecutors and judges due to its opposition to the traditional ways of enforcing justice. ${ }^{22}$ These findings coincide with the public attitudes and stereotypes that the main interest of a prosecutor is to charge the offender.

As far as non-serious crimes are concerned, the results of our research show a very different picture. Prosecutors and judges unanimously support the assumption that peaceful resolution of the conflict and diversion from criminal proceedings, when the grounds provided by law are at hand, brings the best results for the parties and for society. In practice, sometimes they even employ tactics that may induce the parties to seek for rational and peaceful agreement on the resolution of their problems. Sometimes, in the beginning of proceedings, delays are established in order to give some time for the parties to cope with their initial hype of emotions and have a clearer view of different perspectives for the managing of the conflict. Also, parties may be directly encouraged to make a peaceful agreement. But as it has already been mentioned, prosecutors and judges are very cautious concerning the latter as any of their initiatives to divert from the criminal proceedings may be perceived by one of the parties as a corrupt support of the offender, or alternatively a wily tactical move to extract his or her guilty plea.

Respondents mentioned two arguments for their attitudes. First - the professionalorganizational motives. Diversion from criminal proceedings allows prosecutors or judges to save time and effort that may be spent for other more complicated cases, where victimoffender reconciliation is not possible. It significantly reduces pre-trial investigation and allows for the avoiding of a time-consuming trial. Second - the judicial authorities are fully aware that diversion from criminal proceedings may serve the interests of the parties (and of society as well). Victims need to receive actual damage recovery (not only a formal right to damages which may be never accomplished) without delays. Additionally, diversion allows avoiding unnecessary impairments of offenders' legal status and consequent negative

21 Reches 361.

22 Ilona Michailovič, 'Atkuriamojo teisingumo galimybès baudžiamojoje justicijoje [Potential of Restorative Justice in Penal Justice System]' (2014) 6 Globalizacijos iššūkiai baudžiamajai justicijai 85 . 
social results. ${ }^{23}$ Respondents emphasized that whenever legal grounds for diversion existed, peaceful resolution of the conflict between parties was a priority. As far as non-serious offences are concerned, officers do not overestimate public interest in punishing the offenders if the key circumstances are at hand: the offence is cleared, the primary needs of the victim may be satisfied and there are good chances that the offender would experience positive effect from the peaceful resolution of the situation (including minimum risk of reoffending).

The current legal framework allows the parties to reach a peaceful agreement without any mediation proceedings. It may seem to be an even faster and less complicated procedure than mediation. Therefore, we expected some skepticism from the prosecutors and judges regarding victim-offender mediation as an instrument that may create delays in the proceedings and apparently bearing a risk of bringing little (if any) added value. Our hypothesis proved to be wrong. Officers are fully aware of added value of the direct positive contact between parties that could be established during the victim-offender mediation. They agreed that normal conversation between the parties is a necessary precondition for a quick resolution of the conflict situation. It could ease tension, psychological discomfort, fear and anger, which are often the drivers of the aggressive non-cooperative relationships between the parties. The authorities emphasized that the current "shuttle" mode of reconciliation proceedings does not grant the victim a chance to receive direct regret and remorse from the offender nor does it have the potential to make a positive moral impact on the offender. ${ }^{24}$ They also admitted that professional assistance to make a positive contact between a victim and an offender is necessary. Parties often need help to overcome their apathetic or hostile attitudes, to release their relationships from a deadlock. They also need professional guidance, support and safeguarding in the procedure of mediation. Therefore, an impartial and well-trained moderator is needed. Criminal justice authorities admitted that they could not and should not themselves get involved in the active management of conflict between a victim and an offender. Their functions ought to be restricted to the management of the criminal proceedings.

Finally, criminal justice officers agreed that some additional time spent for the relaxation of parties' relationships could be a rational investment of time in the course of the criminal proceedings. It could lead to the overall economy of proceedings and to an outcome that would be satisfactory for the parties and bring peace to the society as well.

\section{PERSPECTIVE}

Our research revealed that Lithuanian prosecutors and judges (at least those included in our research) take rather a rational than formal punitive approach to the conflict management in criminal proceedings both in the discussions and in their daily routine. The Prosecutor General laid down solid grounds for this approach by establishing the priority of diversion of criminal proceedings for non-serious crimes versus completion of pre-trial investigation

23 The attitudes of the officers match the ideas expressed in the Recommendation No. R (99) 19 of the Committee of Ministers to Member States concerning mediation in penal matters and its Explanatory memorandum: "The idea of mediation unites those who want to reconstruct long foregone modes of conflict resolution, those who want to strengthen the position of victims, those who seek alternatives to punishment, and those who want to reduce the expenditure for and workload of the criminal justice system or render this system more effective and efficient."

24 Reches also emphasizes positive moral effects of direct mediation on offender: Reches 359. 
and reference of the case to the court. In addition to the Prosecutor Generals' approach, unfavourable regulations on prosecutors' work-load that discouraged prosecutors from rational solution of the proceedings had been abolished.

The aforementioned idea could be embodied by introduction of mediation into criminal matters and thus providing parties of the criminal proceedings with the still missing professional conflict settlement assistance. The idea of introduction of mediation in criminal proceedings was appreciated by the interviewed judges and prosecutors including the prosecutor at the office of Prosecutor General. What is needed to start providing mediation services? Implementation of the system of mediation services needs political will, legal framework and framework for management of the services. Although political will has been declared already some time ago ${ }^{25}$, taking practical steps have been the hardest task for the Government of Lithuania so far. In 2008, upon the request of the Ministry of Interior, the Law Institute of Lithuania prepared a draft of the Concept of Restorative Justice in Lithuania and Plan of Implementation Measures. After this draft had been prepared it disappeared in the dusty drawers of the Ministry. In November 2013, the Minister of Justice ordered the formation of a working group for the preparation of a draft for the Development of Mediation System Concept (concept again!). ${ }^{26}$ This draft was presented for public discussion in November 2014. However, the concept seems to be very tight and vague on practical issues of introduction of mediation into penal matters. It is a great cause of concern as to whether the concept would be helpful and would boost procedures of introduction of mediation into the Lithuanian criminal justice system. We can only hope that this Concept will avoid the destiny of its predecessor.

What makes us really optimistic about the perspectives of the victim-offender mediation in criminal matters in Lithuania is the Norwegian Grants project "Implementation of Mediation in Probation Services", which was launched by the Probation Service under the Prisons Department in October 2014. The project aims at establishing a long-term system of mediation services although it is designed for two years. The project provides detailed stages of implementation of mediation into penal matters: development of methodology for the implementation of mediation, preparation of mediators' training program, training of 80 mediators in all main regions of the Republic of Lithuania. Under this program the contractors are obliged to provide mediation services for 1500 persons until the end of 2016 (in two years). ${ }^{27}$ Despite the initial fears that low salary would not

25 For example the "Plan of Measures for the Implementation of the Juvenile Justice Programme for 2009-2013", which was established by the decision of the Government of the Republic of Lithuania on 2 September 2009 No 1,070 (measures: to consider perspectives of restorative justice model development in the system of juvenile justice; to identify who could provide services of peacemaking mediation in certain areas; to prepare rules for peacemaking mediation process), "Plan of Measures for the Implementation of the National Program on Crime Prevention and Control for 2007-2009", which was established by the decision of the Government of the Republic of Lithuania on 8 August 2007, No 806 (measure: to prepare the draft of the Concept of the Lithuanian Restorative Justice System and draft of measures for implementation thereof). See in Skirmantas Bikelis, Gintautas Sakalauskas, 'Lithuania' in Friedel Duenkel, Joanna Grzywa-Holten and Philip Horsfield (eds), Restorarive Justice and Mediation in Penal Matters (Forum Verlag Godesberg, 2015) 477-500.

26 Order of Minister of Justice on Development of Mediation System, No 1R-263, 12 November 2013.

27 Vilnius regional probation service, <www.kaldep.lt/lt/vapt/mediacija.html $>$ accessed 5 January 2015. 
attract candidates to vacancies for trainers of mediators (net salary is only 570 EUR a month, which is equal to the average salary in Lithuania) and thus the project would fade in its early stage, it appeared that the call attracted huge interest of candidates (over 70 to 14 vacancies). The successful start of the project is promising. The perspectives of mediation in Lithuania will highly depend on the success of this project.

\section{LITERATURE}

Bikelis, S., Sakalauskas, G., 'Lithuania' in Friedel Duenkel, Joanna Grzywa-Holten and Philip Horsfield (eds), Restorarive Justice and Mediation in Penal Matters (Forum Verlag Godesberg, 2015) 477-500.

Bolívar, D., Aertsen, I. and Vanfraechem, I. (eds), Victims and Restorative Justice: An empirical study of the needs, experiences and position of victims within restorative justice practices (European Forum for Restorative Justice 2013).

Bushman, B. J., Baumeister, R. F. and Phillips, C. M., 'Do People Aggress to Improve Their Mood? Catharsis Beliefs, Affect Regulation Opportunity, and Aggressive Responding' (2001) 81 Journal of Personality and Social Psychology 17-32.

Fattah, E., 'Victim Redress and Victim-Offender Reconciliation in Theory and Practice. Some Personal Reflections' (1999) 35/1 The Hokkaigakuen Law Journal 87-101.

Michailovič, I., 'Atkuriamojo teisingumo galimybès baudžiamojoje justicijoje [Potential of Restorative Justice in Penal Justice System]' (2014) 6 Globalizacijos iššūkiai baudžiamajai justicijai 77-89.

Michailovič, I., Bikelis, S., Čepas, A., Dobrynina, M., Simaitis, R., Šneideris, D., Ūselè, L. and Venckevičienè, J., Atkuriamojo teisingumo perspektyvos Lietuvoje. Restorative Justice Perspectives in Lithuania [Research Series of Law Institute of Lithuania 2014].

Reches, R., 'Psichologinio pasipriešinimo atkuriamajam teisingumui problema' [The Issue of Psychologic Resistance to the Restorative Justice] (2010) 2/6 Socialinių mokslų studijos 357-374. Strang, H., Repair or Revenge: Victims and restorative justice (Oxford University Press 2002). 